\title{
AUTORIŲ KOLEKTYVO PARENGTOS MONOGRAFIJOS „E. SVEIKATOS PLÉTROS INTEGRUOTOS TRANSFORMACIJOS: SUINTERESUOTUUJU PUSIŲ TINKLO PERSPEKTYVA“ RECENZIJA
}

\section{DOI:10.13165/SPV-15-1-8-08}

Naujoji Mykolo Romerio universiteto mokslininkų parengta knyga yra neabejotinai naudinga ne tik mokslo tyrejjams, besigilinantiems ị šios srities teoriją, bet ir žymiai platesniam ratui žmonių - priežiūros specialistams (gydytojams, slaugytojoms, IT specialistams, laboratorijų darbuotojams), pacientams, sveikatos politiką ir IT politiką formuojantiems ir igyvendinantiems sprendimų priemejams, IT firmų darbuotojams, šia tema besidomintiems magistrantūros studentams ir doktorantams. Puikus teorinis pagrindas, vertingi autorių atliktų tyrimų rezultatai bei didžiule praktinio ekspertinio darbo patirtis plačiai perteikiama šioje monografijoje.

Monografiją sudaro septyni skyriai. Pirmajame skyriuje „E. sveikata ir teisinis reguliavimas" atlikta e. sveikatos teisinio reguliavimo ES bei Lietuvoje ir elektroninio sveikatos įrašo teisinio reguliavimo analizè ir suformuluoti pasiūlymai bus naudingi tobulinantiems teisinę aplinką Lietuvoje. Antrajame skyriuje supažindinama su užsienio šalių patirtimi. Trečiasis skyrius „E. sveikatos projektų Lietuvoje analizė“ atskleidžia nagrinejjamų projektų kontekstą, o tai padeda geriau suprasti aplinką, kurioje jie buvo kuriami. Taip pat buvo atlikta atvejo studija konkrečios poliklinikos pavyzdžiu. Ketvirtajame skyriuje „E. sveikatos sistemos naudojimas Lietuvoje vartotojų požiūriu“ pristatomi trijų kiekybinių tyrimų rezultatai, atskleisti e. sveikatos technologijų diegimo proceso ypatumai ir problemos. Penktasis skyriuje „Kokybinis tyrimas: e. sveikatos dalyvių vaidmenys ir problemos" skirtas supažindinti su empiriniame tyrime analizuota sveikatos informacijos skaitmeninimo ir keitimosi šia informacija elektroniniu būdu plètra, analizuojamos plètros neefektyvumo priežastys ir pagrindiniai kliuviniai kuriant e. sveikatos sistemą. Šeštajame skyriuje „E. sveikatos projektų suinteresuotųjų vaidmenys: socialinių tinklų analizė“ pristatomi originalaus kokybinio tyrimo duomenys. Ir galiausiai, septintajame skyriuje, kuris vadinasi „E. sveikatos suinteresuotųjų bendradarbiavimo platforma“ pateikiamas sukurtas ir išbandytas dalyvavimo ir įsitraukimo modelis, kuriuo yra grindžiama e. sveikatos suinteresuotųjų šalių bendradarbiavimo platformos struktūra. 
Ši ịtraukimą ir bendradarbiavimą skatinanti elektroniné platforma yra mokslo įrodymais ir socialinèmis technologijomis pagrịsta pagrindinè politinių organizacinių ir vadybinių priemonių inovacija.

Monografiją rengė grupé mokslininkų, todèl neišvengta kai kurių nežymių stilistinių šios knygos skyrių skirtumų, tačiau tai jokiu būdu nesumenkina atlikto darbo vertès. Monografijos autoriams puikiai pavyko pasiekti išsikeltą tikslą - įvertinti e. sveikatos plètros mastą ir tendencijas iš suinteresuotųjų pusių, kaip svarbiausio e. sveikatos diegimo sèkmès veiksnio, tinklinès perspektyvos siekiant inovatyvumo ir tvarios plètros sveikatos sistemoje. Parengta monografija yra originali savo turiniu, teorinèmis ịžvalgomis, taip pat pristatytais atliktų mokslo tyrimų rezultatais.

Taigi, apibendrindamas pateiktus argumentus manau, kad Danguolès Jankauskienès, Rasos Rotomskienès, Dariaus Štitilio, Vaidos Pukinaitès, Kęstučio Štaro, Birutès Mikulskienès, Birutès Pitrénaitès Žilènienès, Aelitos Skaržauskienès, Rūtos Tamošiūnaitės, Monikos Mačiulienès ir Viktorijos Stokaitès parengta monografija „E. sveikatos plètros integruotos transformacijos: suinteresuotųjų pusių tinklo perspektyva“" - vertinga ir reikalinga knyga.

Prof. dr. Tadas Sudnickas

MRU Politikos ir vadybos fakultetas Vadybos institutas 